\title{
Spiritul critic la Alexandru I. Philippide: Un specialist român la Lipsca
}

\author{
Simona-Andreea Șova* \\ Facultatea de Litere, Universitatea „Alexandru Ioan Cuza”, Bd. Carol I 11, 700506 Iaşi, România
}

\section{Despre articol}

Istoric:

Primit 22 ianuarie 2015

Acceptat 1 martie 2015

Publicat 17 iulie 2015

Cuvinte-cheie:

Philippide

polemică științifică

diacronie

istoria limbii

\begin{abstract}
Rezumat
Beneficiind de consecințele dezvoltării culturale și științifice europene amorsate în secolul al XIX-lea, spațiul românesc a resimțit totodată rămînerile în urmă de pînă atunci. Deficitul de dezvoltare și organizare a științelor şi culturii, calitatea slabă a relațiilor acestora cu complexul social, erau augmentate frecvent nu neapărat prin calitatea slabă a învățaților români, cît printr-o anumită superficialitate a acestora în a aborda și prezenta chestiunile tratate. Încercînd să confere temeinicie, acuratețe și transparență construcției științifice la care participa, A. Philippide a resimțit adesea în mod negativ unele dintre comportamentele și rezultatele științifice prezentate de colegii săi de generație. În acest context, dincolo de calitatea ridicată a rezultatelor sale și de atitudinea sa înalt responsabilă, calea prin care savantul ieșean a încercat ameliorarea procesului a fost cea a polemicii științifice.
\end{abstract}

\section{Preliminarii}

Perioada cuprinsă între secolul al XIX-lea și prima treime a secolului al XX-lea a reprezentat, la nivel european, o perioadă de mare dezvoltare, aproape explozivă la nivel științific, mentalitar și cultural. Descoperirile din diferitele domenii ale științelor naturale, apariția de noi teorii științifice, de noi metode de cercetare și, mai ales, capacitatea învăţaţilor de a privi întregul travaliu ca fiind colaborativ și relativ unitar-rodnic prin asumarea acelorași principii călăuzitoare și prin utilizarea comună a metodelor și a instrumentelorau adus schimbări importante și radicale în științe precum și la nivel cultural-mentalitar. Dezbaterile care au avut loc au depășit ritmul de pînă atunci, științele naturii și metodele cu care acestea operau generînd nu pași, ci salturi și, pe această bază, posibilităţi de progres. Condițiile de circulație și de fructificare a ideilor în spaţiul european erau întocmai cu particularitățile și atmosfera pe care înşiși oamenii le-au creat în diferitele spații spirituale ale Europei. Deși cercetătorii și gînditorii de valoare s-au implicat în prefacerile cultural-științifice din spațiul românesc, diferiți factori au împiedicat folosirea momentului pentru crearea unui cadru solid și favorabil temeinicei receptări a ideilor și, eventual, care să servească drept bază de dezvoltare, inclusiv la nivelul mentalității maselor. Cu toate că existau oameni de o erudiție copleșitoare și avînd o înaltă conștiință a menirii în societate a omului de știință și de cultură (precum Bogdan Petriceicu Hasdeu, Titu Maiorescu, Sextil Puşcariu, A. Philippide), efortul uriaș al acestora nu era neapărat coordonat sau corelat, nici în direcția cercetării propriu-zise, nici în cea a dezvoltării conștiințelor din plan social. Oferind exemplul, fie al sclipirii de geniu, fie al propriei strădanii tenace, fie al combinaţiei acestora, ei s-au străduit să schimbe modalitățile inerţiale de gîndire, tiparele mentalitare, perspectivele asupra destinului uman ca ființă socială și asupra societății ca ansamblu structural-funcțional. Perioada „călare pe două veacuri”, cum o privește Sextil Pușcariu, a fost una a zbuciumului de idei, a chinului social interior, a nevoii de a pune ordine în haosul socio-cultural existent și de a da o nouă direcție culturii, prin raportarea și racordarea acesteia la marile mișcări europene ale spiritului.

*Adresă de corespondență: simona_sova@yahoo.com. 


\section{Savantul}

Dotat cu un excepțional spirit analitic, cu o neostoită sete de a se apropia de realitate, spre a o înțelege și prezenta, cu o capacitate uriașă de a supune propriile idei și cercetări tuturor probelor impuse de știință, renunțînd la ele în cazul în care s-ar dovedi a fi greșite-trăsături definitorii ale multor genii harnice, printre care și Charles Darwin, a cărui Origine a speciilor apare în anul nașterii lui A. Philippide—, dar şi cu o acuitate a spiritului critic care mai mereu ajungea la intransigența aproape autodistructivă, A. Philippide, marele reprezentant, alături de Garabet Ibrăileanu, al spiritului critic ieșean și creatorul Școlii lingvistice de la Iași, este cel care va face lumină în lingvistica românească, deschizînd calea adevăratei cercetări neogramatice, avind la bază filozofia neopozitivistă și spiritul scientist al vremii. Temperament vulcanic și excesiv, de o excepțională erudiție, A. Philippide detesta superficialitatea, oratoria goală, forma fără fond, de aceea societatea contemporană lui i se părea tarată, iar clasa politică, ineficientă, incompetentă şi indolentă. Structurate pe baza unui dialog polemic, lucrările sale științifice demonstrează o libertate de expresie neobişnuită în a-i desființa pe ceilalți-dar și de a le aprecia aportul adus în dezvoltarea culturii române-, critica savantului ieșean fiind orientată cu precădere asupra intelectualului român și străin (Bogdan Petriceicu Hasdeu, Sextil Pușcariu, Ovid Densusianu, Lazăr Șăineanu, Heimann Hariton Tiktin, Gustav Weigand etc.), revelînd „lingvistul realist și omul de o exemplară fermitate în respectul deontologiei culturii” (Pamfil, 2008, p. 90).

\subsection{Direcții de preocupare reflectate în unele scrieri}

Nemulțumit de atmosfera științifică și culturală a epocii sale, la doar 24 de ani, în $1883^{1}$, A. Philippide decide să elaboreze un studiu ce îl dezvăluie pe tînărul dornic să afle și să afirme adevărul, pe cercetătorul lucid și matur în susținerea argumentelor, pe omul inflexibil pe calea adevărului, sever cu sine și cu semenii săi, intransigent prin polemica discursului. Plecind de la studiul aprofundat și critic al teoriilor lingvistice ale lui Timotei Cipariu, B. P. Hasdeu și Alexandru Lambrior, el va elabora scrierea Știința noastră, subintitulată Cum știm. Cum ar trebui să știm. Starea psicologică. Încă de la acest prim pas, savantul român se arată a fi preocupat de metodă și de instrumente, de măsura în care sînt acestea integrate într-o filozofie și călăuzite de principii științifice: „Mă voi încerca, deci, să fixez ordinele de adevăruri, pe cari ar trebui să le caute un romîn în studierea limbei materne, și cari sînt mijloacele cu ajutorul cărora ar putea să ajungă la scopul tendințelor sale știențifice; voi hotărî față cu idealul rezultatele reale ale sforțărilor sale; și, la urmă, voi stabili măsura în care s-a putut apropia de știință inteligența românească” (Philippide, 2006)². Îndreptarea atenției în această direcție arată prin sine înțelegerea clară a modalității în care trebuie să se desfășoare o cercetare autentică și de calitate.

Urmînd cu atenție calea, A. Philippide înțelege că descoperirile învățaţilor europeni, deși deosebit de valoroase, nu sînt suficiente pentru a rezolva problemele lingvisticii românești-a căror soluționare era imperios necesară—și că acest proces trebuia să se producă prin efortul învățaţilor români. În felul acesta, avînd nu doar cunoștințe de lingvistică și o perspectivă filozofică, ci și o bună cunoaștere a domeniului și a nevoilor acestuia, marele lingvist înțelege necesitatea de a rezolva mai întîi unele probleme concrete care țineau lingvistica românească în suferință, punînd, totodată, solide baze conceptuale și de principiu.

În anul 1897 apare Gramatica elementară a limbii române, publicată ca o necesitate, după cum mărturisește autorul în prefață, deoarece informațiile cuprinse de gramaticile epocii nu erau nicicum mulțumitoare: „Pentru istoria limbii române, pe care mi-am propus s-o public... aveam trebuinţă de o gramatică românească, unde să se găsească catalogate formele limbii comune, înțelesurile acestor forme și numeroase

\footnotetext{
${ }^{1}$ Ivănescu (1984) precizează că studiul lui A. Philippide a fost redactat în 1885 (p. XI), însă Andriescu (1983) este de părere că „sînt probe destul de sigure că aceste pagini au fost scrise în anii 1883-1884. Numele lui Lambrior, mort în 1883, este citat de fiecare dată fără să fie însoțit de cuvîntul «domnul», cum se face cu autorii în viață, iar ultima informație bibliografică este din 1884 (Tiktin, Studien zur rumänischen Philologie). Cum A. Philippide era la curent cu tot ceea ce se publica, făcînd cu grijă mențiunile de rigoare, nu rămîne nici o îndoială că studiul acesta nu putea fi scris mai tîrziu de anul menționat” (p. 7).

${ }^{2}$ Citarea respectă întocmai textul autorului, așa cum apare acesta în ediția citată.
} 
exemple. Nici una dintre gramaticile de pînă acum nu-mi putea face însă vreun serviciu, căci, abstracție făcînd de aceea că formele se găsesc ori falş, ori în puțin număr, ori fără sistemă înşirate, exemplele sînt din cale afară de neîndestulătoare: pentru scheletul unei forme se dau trei patru cuvinte ca exemple și apoi un etcetera, iar pentru înțelesul formelor-în studiul căruia dealtfel gramaticii noștri au copiat numai schematismul gramaticilor raționale străine, ori franțuzești ori nemțești—se dau, supt pretext de pedagogie, bucăți de lectură, de unde să-și aleagă, chipurile, elevul cele de trebuință” (Iordan, 1978, p. 80). Fără a deveni o lucrare de căpătîi a gramaticii românești, Gramatica lui A. Philippide rămîne de referință prin bogatul material ilustrativ pentru categoriile morfologice ale limbii noastre, precum şi prin limpezimea concepției de bază. Cel mai important lucru, însă, ține de rostul de bază al acestei scrieri, ea lămurindu-l pe autor asupra unor chestiuni, fiind, adică, un instrument din cadrul unui demers mai larg, indispensabil anumitor stadii de dezvoltate ale științelor.

Specializarea din Germania (1888-1889) îl familiarizează pe A. Philippide cu gîndirea Școlii neogramaticilor, dominată în acea epocă de chiar întemeietorii ei, prin concepțiile lui Hermann Osthoff și Karl Brugmann, expuse în lucrarea Morphologische Untersuchungen. I. Teil, publicată în 1878, Germania, și considerată manifestul acestei școli, după cum arată Ivănescu (1984): „În 1894 nu domina în lingvistica romanică alt curent decît cel neogramatic, pe care Philippide îl cunoscuse chiar la sursă” (p. XV). Aflat în mod structural-organic în acord cu spiritul neogramaticilor, A. Philippide publică în 1894 Principii de istoria limbii, prelucrare cu numeroase contribuții personale a cărții lui Hermann Paul, Prinzipien der Sprachgeschichte, din 1882, numită de Hermann Suchier „Biblia lingvistului”. Lucrarea teoretizează cauzele și regulile după care se schimbă limba, relevînd îndeosebi influența factorului psihic, și contribuie la reformarea concepției despre limbaj, prin explicarea și ilustrarea bogată a cauzelor de schimbare a limbii române de-a lungul existenței sale ${ }^{3}$. Considerînd că limba trăiește prin cei ce o vorbesc, fapt cei determină evoluția, A. Philippide urmărește factorul psihic al limbajului uman și explică modificările limbii prin necesitatea vorbitorilor de a se exprima clar și de a se înțelege unii cu alții. În acest context, A. Philippide formulează trei principii importante ale schimbărilor lingvistice: comoditatea, clarificarea și legiuirea. Comoditatea prezintă dezvoltări precum alunecarea sunetului, analogia, contaminarea, crearea imediată, izolarea, amestecul vorbirilor, ritmul etc. Printr-un proces psihic rămas necunoscut interlocutorului, vorbitorul se străduie să-şi găsească formele gramaticale și cuvintele cele mai potrivite pentru ceea ce vrea el să spună. Această luptă are efecte asupra limbii, prin clarificarea aproape completă a raportului dintre conținutul de idei și exprimarea lui prin cuvinte propriu-zise. Legiuirea reprezintă intervenția voluntară a individului în evoluția limbii și are două subdiviziuni, legiuirea în general și limba scrisă. Se observă că A. Philippide a luat în considerare cauze ale limbii ignorate de $\mathrm{H}$. Paul, precum ritmul, voința, evoluția gîndirii și diferențierea, întîlnite la Humboldt și la Steinthal, concepții cunoscute indirect, prin G. von Gabelentz. De asemenea, ideea schimbărilor fonetice avîndu-şi cauzele în schimbarea conformației și evoluția organelor articulatorii se află în concordanță cu unele opinii din epocă, prezente la Nigra și Osthoff, Schleicher, Ascoli și Schuchardt. Sintagma „organe articulatorii”, întîlnită la Nigra și Osthoff, devine la A. Philippide, „bază de articulație”.

Monumentala operă Originea romînilor, fundamentală pentru lingvistica românească și europeană (vezi Gafton, 2009), demonstrează puterea de muncă științifică și capacitatea de sinteză a lingvistului ieșean, motiv pentru care Iorgu Iordan o consideră „capodoperă a literaturii noastre filologice (în sensul larg al termenului)" (Iordan, 1969, p. 111). Încercarea lui A. Philippide nu constă în a stabili relația în care se află limbile derivate cu o limbă primitivă, ci în a demonstra că ,în feliul de a fi al limbilor, se manifestează înrudirea etnică a neamurilor care le vorbesc" (Philippide, 1928, p. 340). Volumul I, Ce spun izvoarele istorice (1925), urmărește formarea poporului român dintr-un triplu punct de vedere, al locului, al epocii și al modului său de formare. Cele două căi de rezolvare a problemei formulate sînt cea istorică, prin consultarea exhaustivă a izvoarelor scrise, și cea lingvistică, prin studiul limbii române înseși. În volumul

${ }^{3}$ Textul a apărut în Philippide (1894). Aceeași editori (G. Ivănescu și Carmen-Gabriela Pamfil), cărora li se alătură Luminița Botoșineanu, editează Istoria limbii române, apărută la Editura Polirom, în 2011. 
al II-lea, Ce spun limbile română și albaneză (1928), dominat de perspectiva lingvistică, A. Philippide este interesat atît de răspîndirea pe teren a dialectelor românești, analiză realizată printr-un studiu comparativ, cît și de aspectul geografic al originii poporului român și, într-o măsură, de cel etnologic ${ }^{4}$.

\section{Atitudinea polemică}

Efervescența și deschiderile cultural-științifice ale perioadei scoseseră la suprafață felurite atitudini și tendințe prin care se exagera cu intenție forma mimîndu-se fondul, lăsînd cale liberă comportamentelor de tip superficial. Dată fiind temeinica formație de cercetător precum și înalta conștiință a lui A. Philippide, acesta va dezvolta o atitudine critică față de unele dintre rezultatele contemporanilor săi și de prezentarea lor disonantă. Situația era agravată de doi factori: a) acela era un moment care avea nevoie de toată seriozitatea pentru a turna fundațiile unei noi construcții sociale, științifice, mentalitare; b) era absolut inacceptabil ca tentațiile succesului obținut pe căi superficiale să biruie învățați valoroși, pe care A. Philippide îi respecta, a căror știință o recunoștea, fiind modele a căror autoexigență trebuia să fie mult mai mare. Probabil că miza conjugată cu circumstanța generează atitudinea critică impetuoasă și necruțătoare a savantului ieșean.

\subsection{Delimitări teoretice}

Polemica, formă particulară de comunicare conflictuală, indică un schimb verbal, un grupaj de cel puțin două texte care se confruntă și se înfruntă. Metaforic, polemica este un război verbal și discursurile constitutive sînt marcate de o vioiciune, de un caracter agresiv care le diferențiază de dezbatere, dar și de ceartă, care degenerează și duce la înfruntarea pentru sine, conținutul fiind mai puțin important. În cazul discursului științific, polemicitatea este de natură constitutivă, avînd în vedere că orice teorie științifică nouă poate să declanșeze o dezbatere polemică în aria intelectuală în care a apărut, de aceea polemica poate fi văzută și ca o dimensiune constitutivă a logosului.

Oameni de cultură sînt antrenați într-o ceartă în vederea căutării adevărului, fie cu scopul de a-și aduce contribuția la dezvoltarea științei, fie pentru a rosti ultimul cuvînt și a obține supremația într-un domeniu de cunoaștere, polemica devenind „un exercițiu al spiritului prin care se descoperă sau se pune în valoare un adevăr” (George, 1973, p. 61). Astfel, în cazul unei polemici științifice dintre doi savanți nu ar trebui să se pună problema unui învins și a unui învingător, de vreme ce scopul lor este de a dezvălui cititorilor, fie ei avizați sau neavizați, justețea și veridicitatea informațiilor dezbătute.

Polemica ce pune față în față oameni de știință poate să treacă de frontierele domeniului în care a luat naștere și să dobîndească un caracter multidisciplinar. Ea este o manifestare dialogată a fenomenului polemic, bazată pe dialog și reprezintă un tip de interacțiune conflictuală în care se înfruntă doi sau mai mulți locutori distincți ale căror poziții discursive sînt opuse. Schimbul polemic nu se produce mereu față în față, putîndu-se desfășura la distanță, atunci cînd un schimb verbal imediat nu poate avea loc. În polemică se confruntă, așadar, două discursuri, dintre care unul este declanșator, interpretat drept agresor și inițiator al polemicii, iar celălalt, reactiv, marcă a debutului efectiv al polemicii. Polemica se naște la nivelul reacției, în momentul în care există o cristalizare dialogată a unui conflict între două poziționări adverse, datorat unui dezacord profund care îi pune față în față pe protagoniștii săi. Fiind vorba despre o reacție reală, dialogismul este cel mai des generat de o interacțiune internă cu discursul interlocutorului, caz în care el se prezintă sub forma de „dialogism interlocutiv” (Vlad, 2011, p. 201). Ca să descalifice punctul de vedere nou, locutorul îl integrează în propriul discurs prin intermediul unei reluări polemice sau anticipînd o viitoare intervenție a interlocutorului său, pe care o pune sub semnul îndoielii. Această strategie este specifică „dialogismului interlocutiv anticipativ” (Vlad, 2011, p. 201), ce permite, în egală măsură, să anticipăm o posibilă reacție polemică a interlocutorului, cu scopul de a o dezamorsa. Între cei doi polemiști există o etică a demersului intelectual, un stil, niște reguli de conduită care permit dezvoltarea

\footnotetext{
${ }^{4}$ Originea romînilor a cunoscut prima reeditare abia în zilele noastre, făcută de Roxana Vieru, la Editura Universității din Iași apărînd volumul I, în 2014, volumul al doilea urmînd să apară în acest an.
} 
unei polemici constructive, benefice progresului cultural: „Ca în orice conversație, interlocutorii trebuie să vorbească aceeași limbă, măcar pentru elementele principale aflate în dispută. Adversari care vociferează fiecare în parte, nu în legătură cu celălalt, nu polemizează de fapt” (George, 1973, p. 263). De aceea o adevărată polemică este cea care constituie un motiv de respect și de apropiere între adversari, înrudiți pe planul superioarei intelectualităţi.

\subsection{Polemica la Philippide}

Înţelegînd limpede și devreme că nici măcar pentru lingviști forța persuasivă nu decurge din frumusețea expresiei, ci din adevărul științific exprimat ${ }^{5}$, A. Philippide îşi concepe și îşi desfăşoară activitatea dintr-o perspectivă riguros științifică, refuzînd emiterea de judecăți de valoare pornind de la presupuneri sau intuiții-spre deosebire de Hasdeu, de pildă—, și construindu-și discursul pe baza unei bibliografii parcurse și însușite, socotind că orice afirmație trebuie susţinută cu probe științifice. De aceea, operele sale sînt încercări de aflare și descoperire a adevărului, bazate pe consultarea unei uriașe cantități de surse bibliografice, diverse pînă la exhaustivitate, și acelea verificate. În acest context, polemica științifică din scrierile lui A. Philippide este încorporată în discursul științific, ca formă de acțiune vizînd respectarea adevărului știinţific, a căilor de edificare a discursului științific, spre combaterea falsei erudiții-întîlnită la numeroși contemporani-, respingerea nonvalorii reflectate la nivelul unor scrieri (dar și al limbii, unde avea loc abuzul de neologisme, abundînd felurite modalități de exprimare).

Polemica din textele lui A. Philippide, așadar, are două cauze importante: a) nevoia consemnării adevărului științific, prin combaterea cu argumente solide a opiniilor științifice eronate emise de către lingviști străini și români (de exemplu, polemica A. Philippide - Meyer-Lübke din Originea romînilor); b) nemulțumirile personale față de oamenii de știință români, ale căror adevăruri lingvistice erau rodul intuițiilor și al supozițiilor, nicidecum al cercetării științifice minuțioase (de pildă, polemica A. Philippide - Hasdeu $)^{6}$. La A. Philippide, polemica științifică reprezintă un dialog intern, o „polifonie dialogată” (Vlad, 2011, p. 198), o dimensiune interacțională, determinînd coprezența mai multor voci aflate în „,conflict”. Discursul său se înscrie într-un raport cu celălalt și funcționează ca un antagonist ipotetic, de aceea elementul polemic ar putea fi considerat drept o prioritate virtuală.

Polemist prin temperament, A. Philippide și-a dezvoltat spiritul critic cu trecerea timpului și s-a îndreptat adesea chiar împotriva foștilor săi colaboratori, cum ar fi Titu Maiorescu și Ioan Bogdan, din cauza unei recenzii elogioase asupra lucrării Histoire de la langue roumaine, de Ovid Densusianu. Exagerarea cu intenție a formei și adîncile schimbări în viața publică a țării au determinat accentuarea trăsăturii temperamentale a excesului la tînărul A. Philippide, evident și în cîteva dintre articolele sale: Idealuri, Specialistul român. Contribuție la istoriea culturii românești din secolul XIX, Pseudoștiință contemporană etc. În 1892 , în articolul Idealuri, A. Philippide polemizează cu Constantin Dobrogeanu-Gherea, deoarece acesta din urmă le impunea scriitorilor idealuri social-politice progresiste, criticînd societatea cultural-literară Junimea. A. Philippide apără concepția despre artă a Junimii și evidențiază meritele acesteia pentru dezvoltarea culturii românești: „«Junimea», cu începuturile de activitate literară, ieșite din sînul ei, a fost o lumină modestă şi ademenitoare: păcat că pe calea hotărîtă de dînsa, pe calea adecă a muncei serioase, n-am putut noi ceilalți mai tineri să ducem toți lucrul mai departe. [...] Iată cauza pentru care din cercul «Junimii »na ieșit încă atîta lumină cîtă să poată orbi pe un om ca D-l Gherea. «Junimea» a fost însă atît de cuminte că nu s-a umflat ca broasca din fabulă, ea a înțeles că în împrejurările în care trăim de la 1848 încoace, încunjurați și copleșiți de productele inteligenții apusului, nu putem nădăjdui la o literatură națională decît atunci cînd ne vom fi dat mai întîi socoteală de valoarea acelor producte" (Philippide, 1892, p. 156158). Articolul publicat de A. Philippide în „Convorbiri literare” continuă prin descrierea stării de fapt

\footnotetext{
${ }^{5}$ „Persuasiunea se obține prin limpezirea și distingerea ideilor, nu prin împodobirea vorbirii.” (Wald, 1986, p. 64).

${ }^{6}$ Necesitatea spiritului critic în lingvistică este sprijinită, mai tîrziu, și de criticul Dimitrie Macrea: „Într-o epocă în care, în dezvoltarea limbii noastre, s-au manifestat numeroase tendințe exagerate: latinism, italienism, purism, infiltrație de germanisme şi de franțuzisme, beție de cuvinte, caţavencism în oratorie, se impunea cu necesitate acțiunea unui spirit critic lucid și necruțător şi o îndrumare științifică împotriva acestor manifestări." (Macrea, 1978, p. 414).
} 
a societății și a culturii secolului al XIX-lea, apărînd spiritul critic junimist: „N-avem idealuri pentru că am îndrăznit să spunem omului adevărul verde în față, am numit prostul un prost, chiar de ar fi fost el un român, și am început cei dintîi să rupem masca de laude și de umflături pseudopatriotice, toate pornite din idealuri sub care se ascunde goliciunea minții și putreziciunea sufletului...” (Philippide, 1892, p. 155).

După o perioadă de colaborare la „Convorbiri literare”, A. Philippide s-a regăsit în programul lui Garabet Ibrăileanu la „Viața românească” și a început să își publice articolele polemice în paginile acestei reviste. „Viața românească” nu a urmat un program poporanist rigid, iar meritul ei a constat în străduința de a promova o literatură realistă, cu un caracter popular și național, avînd în centru țăranul și luptele lui pentru supraviețuire, fără a fi paravanul vreunor ambiții politice. De aceea, A. Philippide își va publica articolele Cum se apără specialistul român, Dicționarul Academiei sau basmul cucoșului roș, Un specialist român la Lipsca, Coincidențe și Prejudiții, toate cu trimitere fie la semicultura oamenilor timpului său, cu care simțea că nu are nimic în comun, fie la apărarea specificului național. Dubla sa natură este evidenţiată și de Carmen-Gabriela Pamfil, în biografia dedicată lingvistului ieșean: „Philippide a evaluat societatea românească... cu asprimea şi detaşarea neadaptatului şi, totodată, cu angajamentul izvorît din preamultă iubire a autohtonului preocupat de destinul ei” (Pamfil, 2008, p. 22). Un alt punct comun al celor doi oameni de cultură, A. Philippide și Ibrăileanu, l-a constituit respingerea cosmopolitismului și aservirea românească în faţa tuturor modelelor culturale occidentale. Deși lingvistul ieșean s-a format la școli germane, a ales să rămînă în țară pentru a schimba făgașul culturii românești și a păstrat legătura prin corespondență cu unicul său prieten străin, Hermann Suchier. Lingvistul ieșean A. Philippide aderă la ambele direcții susținute de Junimea și „Convorbiri literare”, respectiv, de „Viața românească”, deoarece, de-a lungul timpului, s-a regăsit în fiecare dintre cele două doctrine: la Junimea prin spiritul critic, conservatorismul politic, teoria formelor fără fond, practicarea pozitivismului ${ }^{7}$, iar în revista lui Ibrăileanu, prin poporanism, curentul literar din jurul revistei, ce deplîngea soarta țăranului român.

Teoriile lingvistice formulate de-a lungul timpului suferă modificări, pe de o parte datorită evoluției limbii, pe de altă parte din cauza neștiinței celor care le-au emis. Indignați că au fost contraziși, cei din urmă recurg la răspunsuri umilitoare, insultînd și jignind, ascunzînd neștiința în spatele unei false superiorități sau dincolo de un limbaj defectuos. De exemplu, Gustav Weigand, pe coperta Principiilor de istoria limbii (1894), lucrarea lui A. Philippide, notează aprecieri precum „prostie”, „ridicol” sau „fantastic”, fără a oferi vreun argument în susținerea aprecierilor sale, deși recenziile marilor oameni ai vremii (W. Meyer-Lübke, Hermann Suchier etc.) sînt pline de laude ${ }^{8}$, în timp ce Bogdan Petriceicu Hasdeu alcătuiește articolul intitulat Philippidiotisme. În ceea ce îl privește pe lingvistul ieșean A. Philippide, el nu caută să demonstreze că are mereu dreptate, ci să afle adevărul științific, de aceea depune toate eforturile pentru a cerceta, pentru a reflecta și abia apoi pentru a exprima o judecată corectă, întrucît veritas est in puteo ${ }^{9}$. El se bazează pe corectitudinea puterii de judecată cu care și-a formulat ipotezele, luînd în considerare că ,instrucția potențează puterile înnăscute ale minții” (Horaţiu).

Dacă la Titu Maiorescu, mentorul Junimii, polemica reprezintă paradă intelectuală, erudiție și exprimare sofisticată, la A. Philippide se remarcă stîngăcia exprimării, iar textele abundă în informații științifice, devenind greu de parcurs și de înțeles. La A. Philippide totul este veridic, gîndit, calculat și fără intuiții: „Minte limpede, inteligență superioară, cercetător de o răbdare și de-o putere de muncă ce uimește, pentru el nimic nu pare greu sau cu neputință, cînd e vorba de dezlegarea vreunei probleme filologice. [...] Puțini de tot sînt aceia cari să întrupeze cu atîta rîvnă dragostea pentru adevărul științific, și mai puțin încă aceia cari să rezolve în chip indiscutabil și axiomatic grelele probleme dintr-un domeniu atît de vast și

\footnotetext{
${ }^{7}$ A. Philippide apare ca adept al pozitivismului filozofic în lucrarea Principii de istoria limbii (1894).

${ }^{8}$ W. Meyer-Lübke notează: „Lucrarea este o excelentă introducere în studiul limbilor. [...] a necesitat nu numai o înlocuire a exemplelor germane prin exemple românești, ci o completă pricepere, prelucrare și originală transformare a materialului oferit de un premergător”, iar Hermann Suchier adaugă: „Un merit principal al cărții stă în numeroasele exemple care dau o ocazie autorului să arate profunda cunoștință ce are de limba română, de istoria ei, de literatură și dialectele ei şi să explice astfel o mulțime de fenomene." (apud Grammaticus, 1907, p. 368-369).

9 "Adevărul este îngropat în adîncuri” (Democrit).
} 
atît de puțin exploatat serios, mai ales la noi în țară, ca cel al filologiei” (Dafin, 1927, p. 96). De altfel, A. Philippide însuși mărturisește: „În afară de adevăr nu există folos. Deci [...] toată munca ta, toată silinţa ta este în vînt zvîrlită, cîtă vreme minciuna, gustul de a te arăta mai mult decît ești într-adevăr, ți-ar întuneca mintea cu negurile sale. Umilește-te prin urmare, nu fi prefăcut, nici mincinos, iată ținta la care trebuie să te îndrepți mai înainte de toate" (Philippide, 1892, p. 153).

În privința argumentării propriu-zise, argumentul ad hominem este o problemă majoră în relațiile dintre polemică și retorică. Calificarea sa este, desigur, în funcție de perspectiva adoptată. Într-o perspectivă normativă, argumentul ad hominem nu este în mod clar un argument, ci paradigma vinii în raport cu o practică normată, etico-logică, a argumentării și a controversei. El permite astfel parcurgerea spectrului ce se întinde de la replica rațională asupra obiectului la replica (fie ea insultă sau injurie) ce vizează excluderea persoanei. A. Philippide recurge la atac personal pentru a justifica informațiii răspîndite intenționat eronat: „D-apoi lucrul nu stă așa, ci cu totul altfel. Dl. Pușcariu scrie azi dicționarul Academiei, pentru că n-a voit altul să-l scrie, și acel altul sint eu” (Philippide, 1908, p. 21), pentru a evidenția neconcordanţa dintre esență și aparență identificată în textele unor lingviști: greșelile din dicționarul lui Tiktin ${ }^{10}$ se bazează „pe sărăciea de material, pe sărăciea de exemple, de care dispune autorul şi pe care caută să o ascundă supt aparențele unui om, care nici nu mai știe ce să facă cu mulțimea materialului, de care dispune. [...] Adecă Tiktin n-avea nicio probă, a luat pe una din cele două ale lui Hasdeu fără să citeze pe Hasdeu, a dat-o drept a sa, cum ar fi găsit-o el în psaltirea lui Dosoteiu, edițiea Academiei, a uitat însă că Hasdeu citează după file, iar el citează după pagini ori după numărul psalmului, și s-a prins cu... furătura, căci aceasta se chiamă furătură, plagiat.” (Philippide, 1907, p. 48-50) și pentru a arăta cu degetul minciuna: „Lectorul va zice că, dacă a ajuns Dl. Hasdeu cu lectura la pag. 119, trebue să fi citit cele 118 pagini precedente. Ei bine, lectorul se înșeală. Dl. Hasdeu n-a citit nici pe Sievers, nici pe nime altul din autorii însemnați cu băgare de samă în notița bibliografică și citați cînd de ici cind de dincolo. Dl. Hadeu nu știe din fisiologiea sunetelor nimic" (Philippide, 1907, p. 74).

În intenția sa de a face lumină printre teoriile lingvistice emise greșit, situație ingrată de multe ori, polemistul A. Philippide dă dovadă de spirit critic, perspectivă diacronică și de dorința de a corecta, caracteristici surprinse de G. Călinescu, într-un scurt dialog: „- Ai de gând să spui adevărul, să afirmi ce e bun şi ce e rău?/ - Da!/ - Atunci ești un om pierdut. [...] Pentru că toți cei asupra cărora vei spune un adevăr defavorabil vor declara că-i «înjuri». [...] Ei te vor calomnia că ataci din duşmănii personale, vor căuta să te discrediteze în ochii publicului și vor izbuti să-ți facă o atmosferă defavorabilă./ - Nu mă sperii nici de injurii, nici de tăcere. Cine stă alături de adevăr nu poate să nu învingă. Căci încetul cu încetul, pe măsură ce se ridică noi generații, falsele valori dispar și tu te vei afla deodată scăpat de vechii dușmani” (Călinescu, 1988, p. 99-101).

\section{Un specialist român la Lipsca}

Studiul Un specialist român la Lipsca prezintă un discurs critic ce abundă în elemente de expresivitate, caracteristică a textului cu originea în stările sufletești ale subiectului vorbitor. Textul lingvistic reflectă reacția emițătorului față de subiectul în discuție și raportul în care se află cu dimensiunea estetică a limbii: A. Philippide este revoltat de aberaţiile lingvistice expuse de Gustav Weigand, profesor la universitatea din Leipzig, și, totodată, contrariat de puternica susținere pe care un lingvist străin, pseudospecialist al limbii române, o are din partea statului român, în vreme ce oamenii de știință ai țării nu sînt încurajaţi (vezi Dumistrăcel, 2009, p. 27-42). Astfel, una dintre funcțiile textului este cea expresivă, deoarece reliefează perspectiva individualității intelectuale și afective, dar și a manifestării emiţătorului. Combinarea în planul sintagmatic al textului, ca operație a comunicării scrise sau orale, reliefează și atitudinea emițătorului, întrucît, „cine vorbește comunică și se comunică” (Tudor Vianu): infirmare categorică, respectiv, indignare - Imposibil! (Philippide, 1909, p. 25), ironie, prin utilizarea atributului adjectival aflat în inversiune, fine - „Ce fine observații! «muldare» după «căldare»!” (p. 10), surprindere și respingere disprețuitoare

\footnotetext{
${ }^{10}$ Este vorba despre dicționarul Rumänisch-deutsches Wörterbuch, I. A-C, Bukarest, 1895.
} 
a spuselor lui Gustav Weigand - „Ferească Dumnezeu!” (p. 38), dispreț - „Bătaie de joc, nu altă ceva!” (p. 64), hotărîre și respingere prin întrebuințarea adverbului negativ nu în formă exclamativă $-N u$ ! (p. 35) sau prin antifrază - „Are simț fin pentru limbi Dl. Weigand!” (p. 64), „Dl. Weigand iubește neamul românesc! Iaca o fericire. [...] Parcă ar fi vorba de împăratul Napoleon!” (p. 158).

Nemulțumirile lingvistice îi vizează și pe oamenii de știință români, cum ar fi Sextil Pușcariu, căruia A. Philippide îi reproșează lipsa de precizie în formularea pozițiilor pe care el le adoptă sau modul în care înțelege să le apere, precum și eventualele contradicții dintre diversele sale luări de poziție: „După cum dispune Dl. Pușcariu în mod arbitrar pe terenul limbii latine populare, așa că inventează tot feliul de lucruri de care are trebuință, cuvinte, sufixe, fonetizme, tot așa de arbitrar procedează D-sa și pe terenul propriu al limbii românești. Schimbarea lui $k, g, t, d$, urmate de $\breve{i}(i$ consonant) în $t s, t \check{s}, d z$, $d \check{z}$ este o schimbare anteromânească, ea a avut loc în limba latină populară. Pe terenul propriu al limbii române sunetele $k, g, t, d$, dacă s-au mai găsit vreodată în contact cu un $\breve{\imath}$ următor, au rămas $k, g, t, d$ și nu s-au mai prefăcut în $t s, t s ̌, d z, d \check{z}$. Dl. Pușcariu nu vrea să țină socoteală de acest lucru" (Philippide, 1909, p. 123).

Savantul A. Philippide a impresionat prin corectitudinea surprinderii adevărului de natură științifică şi prin curajul de a demonta impostura și falsitatea întîlnite la oamenii de cultură. Elementele de etos ale adversarilor, invocate în argumentările lui, nu sînt relevate pentru a discredita lingviști români sau străini și a se ridica pe sine, ci în vederea evidențierii unei stări morale, a inculturii, a unor trăsături umane negative, caracteristice „specialiștilor” vremurilor lui, spre denudarea stării de fapt. Studiul Un specialist român la Lipsca cuprinde mici elemente de portret ale lingvistului german Gustav Weigand, realizat de A. Philippide: „[...] profesorul de la civilizata Lipscă vrea să încătușeze gîndul liber al unui om din răzbunare personală, și pe ascuns, prin scrisorele și prin intrigi. Mai frumoasă purtare nici că se poate. [...] Dl. Weigand însă înjură oamenii și aceasta m-a făcut să-mi ies din sărite. Vorbe grele ca neruşinat, stupid îi curg din gură. [...] ar trebui Dl Weigand să se ferească ca de foc de a mai da oamenilor epitete ca—mi-i rușine că trebue să le pomenesc_stupid, ori neruşinat, ori mizerabil" (Philippide, 1909, p. 159-160). Locurile, temporalitatea şi etosul protagoniştilor nu constituie simple „circumstanțe”, ci fac parte integrantă din strategiile polemice, al căror obiectiv este reducerea la tăcere a adversarului și ridiculizarea acestuia cu orice preț. Dialogul stabilit între lingviști aduce elemente de ironie, de umor și de satiră din partea lingvistului ieșean: „Eu aș propune în onoarea D-lui Weigand, care ne-a amuzat pînă acum și încă are să ne amuzeze, să introducem pentru acest înțeles cuvîntul «vaigîndesc». Acest cuvînt are mai multe avantaje. Întîiu e vîrît în grupa cuvîntului «gîndesc», aşa că conjugarea lui nu prezintă nici o dificultate. Apoi ne aduce aminte de Dl. Weigand. În sfîrșit formează și un calambur, «vai, gîndește!», care calambur e foarte potrivit din toate punctele de videre" (Philippide, 1909, p. 50).

De aceea A. Philippide intră într-o confruntare cu lingvistul „specialist” în vederea cunoașterii adevărului științific și a căilor de lămurire în continuare. Interpretată drept un drum spre adevăr, ironia este una dintre „armele” lui A. Philippide, iar locutorul recurge la remarci ironice pe baza textului supus analizei sau în titlul ales de el. De exemplu, pronumele de politețe $D$-sale surprinde atitudinea ironică a emițătorului, manifestare depreciativă întărită de folosirea adjectivului antepus „poreclita” („[Weigand] ne stîlcește limba în poreclita D-sale gramatică românească”).

Expresivitatea este o manifestare a componentei afective, ironice, determinate de superficialitatea ,specialiștilor" contemporani lui A. Philippide. Gradul maxim de expresivitate a mesajului este atins prin folosirea interjecției afective vai!: „Vai, ce năcaz! Să ajungem în doaga copiilor de clasele primare într-o discuție de analiză gramaticală cu un profesor universitar dela Lipsca!” (Philippide, 1909, p. 60). Prin utilizarea interjecției volitive $i a$, A. Philippide îndeamnă la o anumită atitudine, de revelare a adevărului: „Apoi ia să stăm puțintel de vorbă” (p. 5). Enunțurile asertive exclamative sînt dublate de interogațiile retorice, din dorința de a impune lectorului un anumit punct de vedere și pentru a-l face părtaş la un anumit mod de a considera problema în discuție. Nemulțumit de descoperirile lingvistice ale lui Weigand în limba română, A. Philippide le respinge cu sarcasm sau cu uimire: „Cine nu știe că «m» final a căzut deja din limba latină populară?” (p. 20), „Ori unde să-l mai fi găsit Dl. Weigand pe «veaia»?” (p. 25), „Cum i-a putut trece prin cap D-lui Weigand una ca aceasta?” (p. 32), „Ce înseamnă această harababură?” 
(p. 32), „Nu cumva inventează Dl. Weigand lucrurile de care are trebuință?” (p. 25), „Ce-i asta?” (p. 36) etc. Pentru a fi mai persuasiv, lingvistul ieșean și-l ia ca martor chiar pe lector, devenit subiect al unor propoziții interogative și căruia i se adresează direct: „Socoți că are să mă creadă cineva din cercurile cele înalte?” (p. 141), „Știți ce spune Dl. Weigand?” (p. 5), „Cum credeți că a înțeles Dl. Weigand?” (p. 10).

\section{Concluzii}

În cele din urmă, om de știință, polemistul este interesat de rigoarea demonstrației sale, de cumpănirea judecății, de spiritul de justețe și de relevarea adevărului, optimism suprins în vorbele înțelepte ale cronicarului: „birui-va gîndul!”. De aceea, se poate spune că discursul polemic al lui A. Philippide este unul de idei, nu de cuvinte. Relevarea adevărului și înlăturarea ideilor mincinoase, lipsite de justețe, determină o evoluție culturală: „Ușoară sau nu, critica a fost și va rămîne o lucrare necesară în viața publică a unui popor. Înțelegerea răului este o parte a îndreptării” (Maiorescu, 1984, p. 105).

Într-un sens, A. Philippide era un idealist, iar idealismul său era pus la grea încercare de frămîntările vieții politice din vremea sa. Între opinia lui asupra modului în care trebuie să funcționeze o societate și realitatea timpului pe care îl trăia exista o mare diferență, urmarea fiind disprețul și vizibila izolare de lume. O probă categorică a orientării sale spre viața culturală o arată neimplicarea în politica militantă, spre deosebire de Hasdeu, Titu Maiorescu, Sextil Pușcariu sau Ovid Densusianu, a căror activitate științifică a fost strîns legată de problemele vremii: „Alexandru Philippide a avut o activitate obștească redusă. El a fost tipul savantului absorbit de munca de cercetare, retras și puțin comunicativ. Această situație este ilustrată, între altele, de faptul că din 1914 și pînă la moarte el n-a mai părăsit niciodată Iașiul. Nu a mai luat de atunci parte nici la ședințele Academiei, al cărui membru titular era încă din 1900” (Macrea, 1978, p. 195). A. Philippide își făcuse un ideal de viață, pentru el „adevărul, dreptatea, cinstea și alte noțiuni similare din punct de vedere etic erau un fel de entități cu existență reală, oarecum concretă, întocmai ca atîtea noțiuni materiale, palpabile, care pot fi sesizate și cunoscute cu toată exactitatea și precizia, grație materialităţii lor. [...] El însuși se ostenea să se conformeze, pînă la ultimele limite posibile, acestor elemente alcătuitoare ale omului adevărat și era convins că se conformează. Totodată, pretindea însă și semenilor săi, considerați fie ca indivizi, fie în grup, să facă același lucru” (Iordan, 1969, p. 26).

Prin urmare, fie că încercăm să o eliminăm, să o ascundem în spatele unei evidențe fictive, ca și cum totul ar merge de la sine, sau, dimpotrivă, fie că o afișăm pe scenă ostentativ în scopuri strategice, polemica rămîne, cel puțin în stare latentă, în centrul oricărui demers științific. Iată de ce a-i neglija pertinența nu are niciodată ca efect decît să mascheze, chiar să respingă ideea esenţială potrivit căreia la baza oricărui discurs polemic se află o cauză de cîștigat, un adversar care trebuie scos din joc prin argumente care trebuie contestate și printr-un public care necesită a fi convins de superioritatea unei viziuni a lumii înscrise într-o ierarhie a valorilor și a preferințelor.

\section{Bibliografie}

Andriescu, Al. (1983). Actualitatea lui Alexandru Philippide, în Alexandru Philippide: 50 de ani de la moarte, Iaşi.

Călinescu, G. (1988). Însemnări şi polemici, Editura Minerva, Bucureşti.

Dafin, I. (1927). Figuri ię̧ene, ediția a II-a, Editura Viața Românească, Iaşi.

Dumistrăcel, S. (2009). Alexandru Philippide - Gustav Weigand: ipostaze, în „Philologica Jassyensia”, anul V, nr. 1 (9), p. $27-42$. Gafton, Al. (2007). Polemica ştiințifică la G. Ivănescu, în „Analele Ştiințifice ale Universității «Alexandru Ioan Cuza», din Iaşi”, seria III. Lingvistică, t. LIII, volum omagial Vasile Arvinte, p. 475-483.

Gafton, Al. (2009). «Originea romînilor» - piatră de temelie a ŞColii lingvistice de la Iaşi, în „Philologica Jassyensia”, anul V, nr. $1(9)$, p. $51-55$.

George, Al. (1973). La sfîrşitul lecturii, vol. I-III, Editura Cartea Românească, Bucureşti.

Grammaticus (1907). „Adevărurile d-lui Puşcariu”, în „Viața românească”, nr. 2, anul II, p. 368-372.

Iordan, I. (1969). Alexandru I. Philippide, Editura Ştiinţifică, Bucureşti.

Iordan, I. (coord.) (1978). Istoria lingvisticii româneşti, Editura Ştiinţifică şi Enciclopedică, Bucureşti.

Irimia, D. (1999). Introducere în stilistică, Editura Polirom, Iaşi. 
Ivănescu, Gh. (1984). Alexandru Philippide - teoretician al limbajului, în volumul Opere alese. Teoria limbii, ediție îngrijită de G. Ivănescu şi Carmen-Gabriela Pamfil, Editura Academiei Române, Bucureşti.

Kerbrat-Orecchioni, C. (1980). La polémique et ses définitions, în Le discours polémique, Presses Universitaires de Lyon, Lyon. Lesovici, M.D. (1999). Ironia. Ipostaze în poezia română contemporană, prefaţă de Liviu Leonte, Institutul European, Iaşi. Macrea, D. (1978). Contribuții la istoria lingvisticii şi fllologiei româneşti, Editura Ştiințifică şi Enciclopedică, Bucureşti. Maiorescu, T. (1984). Observări polemice (1869), în Critice, volumul I, Editura Minerva, Bucureşti.

Pamfil, C.-G. (2008). Alexandru Philippide, Editura Litera Internaţional, Bucureşti-Chişinău.

Philippide, Al. (1892). Idealuri, în „Convorbiri literare”, XXV, nr. 11-12, p. 1015-1023; XXVII, nr. 4, p. 289-320.

Philippide, Al. (1894). Istoria limbii române, I. Principii de istoria limbii, Tipografia Națională, Iaşi.

Philippide, Al. (1907). Specialistul român. Contribuție la istoriea culturii românești din secolul XIX, Editura „Vieții românești”, Iaşi.

Philippide, Al. (1908). Cum se apără specialistul român, în „Viața românească, III, volumul VIII, nr. 2, p. 16-28.

Philippide, Al. (1909). Un specialist român la Lipsca, Tipografia Dacia P.\&D. Iliescu, Iaşi.

Philippide, Al. (1928). Originea romînilor, II. Ce spun limbile romînă și albaneză, Tipografia „Viața românească” S.A., Iași.

Philippide, Al. (2006). Ştiința noastră. Cum ştim. Cum ar trebui să ştim. Starea psicologică. Manuscris aflat la Biblioteca Filialei Iaşi a Academiei Române, fondul Alexandru I. Philippide. Lucrarea a fost editată de G. Ivănescu şi Carmen-Gabriela Pamfil, cu o postfață de Al. Andriescu, în „Analele Universității «Ştefan cel Mare» Suceava”, Seria Filologie, A. Lingvistică, XII, 2006, nr. 1.

Plantin, Chr. (2003). Des polémistes aux polémiqueurs, în La parole polémique, de Gilles Declerq, Michel Murat, Jacqueline Dangel, Honoré Champion, Paris.

Schopenhauer, A. (2012), Arta de a avea întotdeauna dreptate sau Dialectica eristică, text stabilit, traducere din limba germană, prefaţă şi note de Gabriel H. Decuble, Editura Art, Bucureşti.

Vlad, D. (2011). La polémique entre scientifiques: une approche polyphonique, în „Studii de lingvistică”, nr. 1, p. 197-212.

Wald, H. (1986). Expresivitatea ideilor, Editura Cartea Românească. 